\title{
Helicobacter baculiformis sp. nov., isolated from feline stomach mucosa
}

Correspondence

M. Baele

Margo.Baele@UGent.be
M. Baele, ${ }^{1}$ A. Decostere, ${ }^{1}$ P. Vandamme, ${ }^{2}$ K. Van den Bulck, ${ }^{1}$ I. Gruntar, ${ }^{3}$ J. Mehle, ${ }^{3}$ J. Mast, ${ }^{4}$ R. Ducatelle ${ }^{1}$ and F. Haesebrouck ${ }^{1}$

\footnotetext{
${ }^{1}$ Department of Pathology, Bacteriology and Avian Diseases, Faculty of Veterinary Medicine, Ghent University, Salisburylaan 133, B-9820 Merelbeke, Belgium

${ }^{2}$ Department of Biochemistry, Physiology and Microbiology, Faculty of Sciences, Ghent University, Ledeganckstraat 35, B-9000 Ghent, Belgium

${ }^{3}$ Institute of Microbiology and Parasitology, Veterinary Faculty, University of Ljubljana, Gerbiceva 60, 1000 Ljubljana, Slovenia

${ }^{4}$ CODA - CERVA - VAR, Groeselenberg 99, B-1180 Brussels, Belgium
}

\begin{abstract}
A Gram-negative, microaerophilic slender rod, measuring approximately $10 \mu \mathrm{m}$ long and approximately $1 \mu \mathrm{m}$ wide, isolated from the gastric mucosa of a cat and designated strain $\mathrm{M}_{50}{ }^{\top}$, was subjected to a polyphasic taxonomic study. Despite its apparent lack of helical coils, the organism showed a corkscrew-like motion by means of multiple sheathed flagella located at both ends of the cell and by a periplasmic fibril coiled around the body. Strain $\mathrm{M}^{\circ} \mathrm{O}^{\top}$ grew preferably on biphasic culture plates or on very moist agar. Coccoid forms predominated in cultures older than 4 days as well as in growth obtained on dry agar plates. The strain grew at $37{ }^{\circ} \mathrm{C}$, but not at 25 or $42{ }^{\circ} \mathrm{C}$ and exhibited urease, oxidase and catalase activities. On the basis of $16 \mathrm{~S}$ rRNA gene sequence analysis, the novel isolate was identified as a member of the genus Helicobacter and showed about 98 to $99 \%$ sequence similarity to Helicobacter felis, Helicobacter bizzozeronii, Helicobacter salomonis, Helicobacter cynogastricus and 'Candidatus Helicobacter heilmannii', five highly related species previously detected in the feline or canine gastric mucosa. Protein profiling of strain $\mathrm{M}^{\top} \mathrm{O}^{\top}$ using SDS-PAGE revealed a pattern different from those of other Helicobacter species of mammalian gastric origin. Additionally, the urease and HSP60 gene

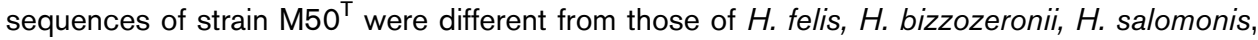
$H$. cynogastricus and ' $\mathrm{Ca}$. $\mathrm{H}$. heilmannii'. It is thus proposed that strain $\mathrm{M}^{\mathrm{T}} \mathrm{O}^{\top}$ (=LMG $23839^{\top}=$ CCUG $53816^{\top}$ ) represents a novel species within this genus, for which the name Helicobacter baculiformis sp. nov. is proposed.
\end{abstract}

Several highly related Helicobacter species have been isolated from the stomachs of dogs and cats. Helicobacter felis was isolated for the first time from the stomach of a cat and was subsequently also isolated from canine gastric mucosa (Lee et al., 1988). Two other species have been described after their isolation from dog stomachs, namely Helicobacter bizzozeronii and Helicobacter salomonis (Hänninen et al., 1996; Jalava et al., 1997). The prevalence

Abbreviations: PAGE, polyacrylamide gel electrophoresis; TEM, transmission electron microscopy.

The GenBank/EMBL/DDBJ accession numbers for the 16S rRNA, partial ure $A B$ and $h s p 60$ gene sequences of $H$. baculiformis $M 50^{\top}$ are EF070342, EF070343 and EF070344, respectively.

Supplementary tables showing the distance matrix values for the Helicobacter strains examined in this study based on $16 \mathrm{~S}$ rRNA, ure $A B$ and $h s p 60$ gene sequences are available with the online version of this paper. of $H$. bizzozeronii, $H$. felis and $H$. salomonis in the stomachs of 110 dogs and 43 cats was investigated by a multiplex PCR and it was found that in cats, H. felis (63\%) and H. bizzozeronii (35\%) were the most predominant species, while only $2.3 \%$ of the animals were colonized by $H$. salomonis (Van den Bulck et al., 2005). Based on 16S rRNA gene sequence analysis, all three species are phylogenetically very highly related to each other and to 'Helicobacter heilmannii type 2 organisms, detected in the human gastric mucosa (Solnick et al., 1993). The similarity of the ureAB urease genes of the three species is, however, lower than $85 \%$, allowing discrimination between these species. A fourth uncultured species has been detected in wild feline and in human gastric biopsies by PCR. Sequencing analysis of urease genes showed sufficient differences to those of $H$. felis, $H$. bizzozeronii and $H$. salomonis and this fourth uncultured species was provisionally named 'Candidatus Helicobacter heilmannii' (O’Rourke et al., 2004). Recently, 
another isolate from the stomach of a dog was described as Helicobacter cynogastricus after a polyphasic taxonomic study (Van den Bulck et al., 2006).

Bacteria with a corkscrew-like motion similar to that of species of the genus Helicobacter but with a different morphology have been isolated from animals and humans and are designated as 'Flexispira rappini' (Eaton et al., 1996). This is a provisional name given to Gram-negative, microaerophilic, motile, fusiform-shaped organisms with spiral periplasmic fibres and bipolar tufts of sheathed flagella, which explain the corkscrew movement. Phylogenetic analysis of several 'Flexispira rappini' isolates from sheep, pigs, rodents, dogs and primates has shown that these all belong to the genus Helicobacter. Strains belonging to flexispira taxa $1,4,5$ and 6 have been described as Helicobacter trogontum (Dewhirst et al., 2000a; Hänninen et al., 2003; Mendes et al., 1996), while Helicobacter bilis comprises taxa 2, 3, 8 and 9 (Dewhirst et al., 2000a; Hänninen et al., 2005). H. bilis was also isolated from feline faeces (Hänninen et al., 2005), but until now, no organisms with a flexispira morphology have been described that colonize the feline stomach. Helicobacter sp. flexispira taxon 7 comprised one isolate from a dog's stomach (Dewhirst et al., 2000a; Eaton et al., 1996).

In this study, we describe the isolation and characterization of a Helicobacter strain with flexispira-like morphology, isolated from the stomach mucosa of a cat.

The novel strain, designated $\mathrm{M} 50^{\mathrm{T}}$, was isolated from the mucosa of the stomach of a cat euthanized at the Veterinary Faculty, University of Ljubljana, Slovenia. Tissue samples were handled as described by Gruntar et al. (2003). Bacteria were grown on fresh Columbia agar plates (Oxoid) containing $7 \%$ defibrinated and lysed horse blood, $7 \%$ defibrinated and lysed sheep blood, vancomycin (5 $\mathrm{mg} \mathrm{l}^{-1}$; Sigma), trimethoprim ( $3 \mathrm{mg} \mathrm{l}^{-1}$; Sigma), polymyxin B (2500 $\mathrm{U} \mathrm{l}^{-1}$; Sigma) and amphotericin B (Fungizone; $5 \mathrm{mg} \mathrm{l}^{-1}$; Bristol-Myers Squibb). Plates were incubated with lids uppermost at $37{ }^{\circ} \mathrm{C}$ under humidified microaerophilic conditions in a closed circuit that was created by evacuating $75 \%$ of the normal atmosphere and introducing a gas mixture of $6.7 \% \mathrm{CO}_{2}, 1.3 \% \mathrm{H}_{2}$ and $92 \%$ $\mathrm{N}_{2}$. Plates were checked every two days and BHI broth supplemented with $20 \%$ horse serum (Sigma) and $20 \%$ yeast extract (Biolife) was added to the agar surface to ensure that the plates did not dry out. Primary growth was detected after 3 days of incubation by examination of the broth by dark-field microscopy, revealing the presence of large, rod-shaped and motile bacterial cells. Growth of subcultures occurred as a spreading layer on moist agar plates. Rapid oxidase, catalase and urease tests were positive and the isolate was unable to grow aerobically. Gram staining revealed that the isolate was Gram-negative and had a bacillary shape. Pinpoint colonies were observed when an abundant amount of bacteria was inoculated onto a dry agar surface; however, bacteria grown on such a medium mainly lost their bacillary morphology and transformed to coccoid forms. The isolate was stored in sterile skimmed milk with $15 \%$ glycerol at $-70{ }^{\circ} \mathrm{C}$ for later studies.

Genomic DNA of strain $\mathrm{M} 50^{\mathrm{T}}$ was extracted using the DNeasy Tissue kit (Qiagen) according to the manufacturer's instructions.

The 16S rRNA gene was amplified using the commercially available Qiagen Taq Mastermix, to which primers $\alpha \beta$ NOT (5'-AGTTTGATCCTGGCTCAG-3') and $\omega \mathrm{MB}\left(5^{\prime}-\right.$ TACCTTGTTACGACTTCGTCCCA- $3^{\prime}$ ) were added at a concentration of $0.2 \mathrm{mM}$. The PCR products were sequenced using the BigDye Terminator sequencing kit (Applied Biosystems) and primers $\mathrm{pD}, \gamma^{*}, 3$ and $\mathrm{O}^{*}$ (Coenye et al., 1999), as described previously (Baele et al., 2001), and determined on a DNA sequencer (ABI Prism 3100 Genetic Analyzer, Applied Biosystems). The electropherograms were exported and converted to KODON (Applied Maths). The sequences were compared with the NCBI GenBank by using the BLAST search tool. Phylogenetic analysis was performed using the KODON software after including the consensus sequence in an alignment of small ribosomal subunit sequences collected from GenBank. The $16 \mathrm{~S}$ rRNA gene of strain $\mathrm{M} 50^{\mathrm{T}}$ (GenBank accession no. EF070342) showed 98-99\% sequence similarity with ' $H$. heilmannii' type $2, H$. felis, $H$. salomonis and H. bizzozeronii.

Multiple alignment was calculated using an open gap penalty of $100 \%$ and a unit gap penalty of $0 \%$. A tree was constructed using the neighbour-joining method. The dendrogram is shown in Fig. 1 and strain $\mathrm{M}^{\mathrm{T}} 0^{\mathrm{T}}$ was situated near the $H$. felis, $H$. bizzozeronii, $H$. salomonis, $H$. cynogastricus, and ' $\mathrm{Ca}$. H. heilmannii' cluster. These species have all been isolated from the stomachs of dogs (Hänninen et al., 1996; Jalava et al., 1997; Van den Bulck et al., 2006), cats (Lee et al., 1988; O'Rourke et al., 2004) and/or humans (Andersen et al., 1999; Jalava et al., 2001; O’Rourke et al., 2004). Only 90.7\% 16S rRNA gene sequence similarity was found to 'Flexispira rappini' taxon 7, comprising a Helicobacter isolate from a dog stomach (accession no. U51874). Multiple aligned distances, as calculated using KODON, are shown in Supplementary Table S1 (available at IJSEM Online).

In an attempt to identify strain $\mathrm{M} 50^{\mathrm{T}}$ to the species level, a multiplex PCR was performed that enables discrimination between $H$. felis, $H$. bizzozeronii and $H$. salomonis. This PCR is based on a part of the tRNA intergenic spacer of Helicobacter species, amplified with TET-labelled primers, and on the urease gene of $H$. felis (NED-labelled primers) and $H$. bizzozeronii (HEX-labelled primers), as described earlier (Baele et al., 2004).

DNA extracted from pure cultures of H. felis, H. salomonis and $H$. bizzozeronii served as positive controls, while highly purified water was included as a negative control. Fluorescently labelled PCR products were separated by 


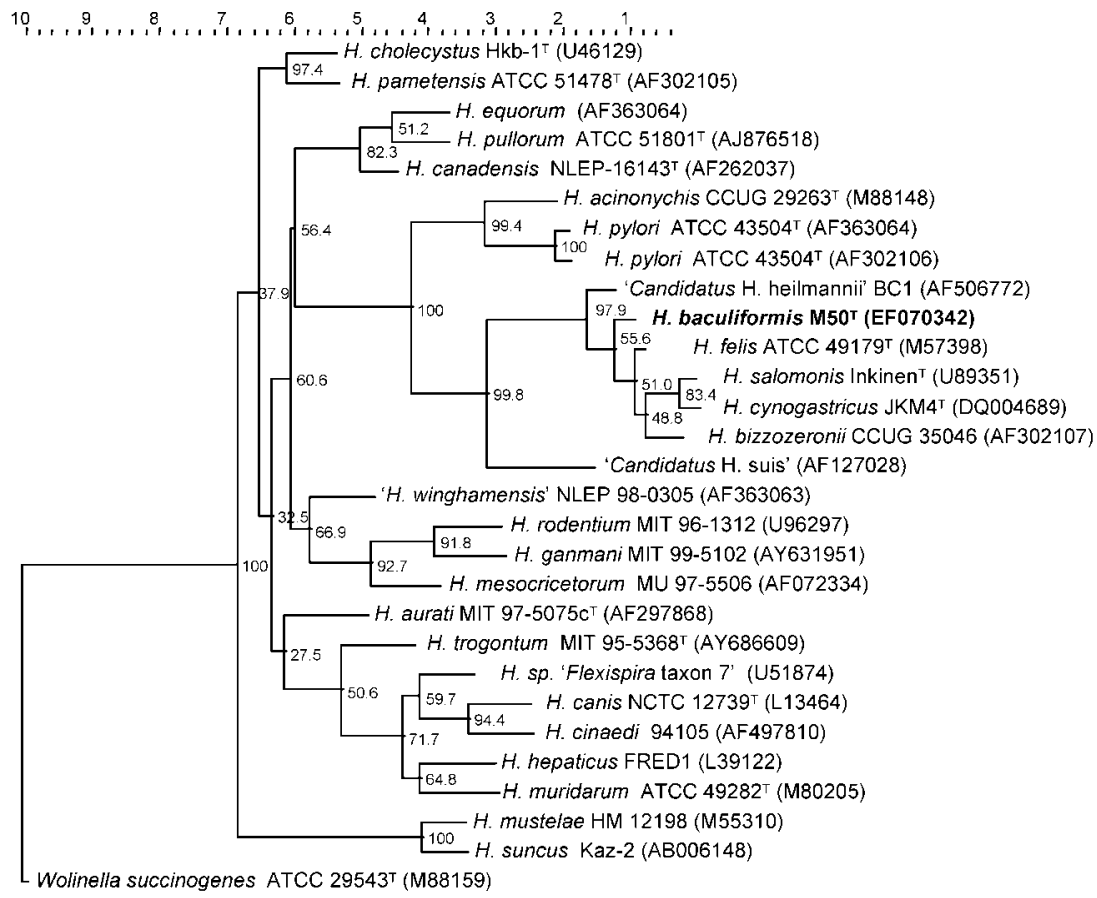

Fig. 1. Phylogenetic tree for 28 Helicobacter strains based on 16S rRNA gene sequence similarity data. The numbers by the branches indicate the number of times out of 100 that the clade was recovered by bootstrap resampling (number of bootstraps: 1000). Bar, 10\% sequence divergence. means of capillary electrophoresis using an ABI Prism 3100 Genetic Analyzer (Applied Biosystems). Product lengths were determined by interpolation with an internal size standard mixture of GENESCAN 500 ROX (Applied Biosystems) and GENESCAN 400-HD ROX (Applied Biosystems) using GeneMapper (Applied Biosystems).

Strain $\mathrm{M} 50^{\mathrm{T}}$ yielded an amplicon of $137 \mathrm{bp}$ with the tRNA intergenic spacer-specific primers, which is the same as the amplicon obtained for $H$. felis strains. However, no $H$. felisspecific urease gene fragment was obtained with the NEDlabelled primers.
The sequences of the urease genes $u r e A$ and $u r e B$ have been shown to be more discriminative than the 16S rRNA gene sequence and are thus very useful for phylogenetic analysis of gastric Helicobacter species (O'Rourke et al., 2004). A 1224 bp fragment of the $u r e A B$ genes was amplified and sequenced using primers U430F and U1735R and with conditions as described above. A sequence of 1072 bp (GenBank accession no. EF070343) was obtained and showed about $80 \%$ similarity with the urease sequence of H. felis strain INTO (AY368267).

Multiple alignment was calculated using an open gap penalty of $100 \%$ and a unit gap penalty of $0 \%$. A tree was

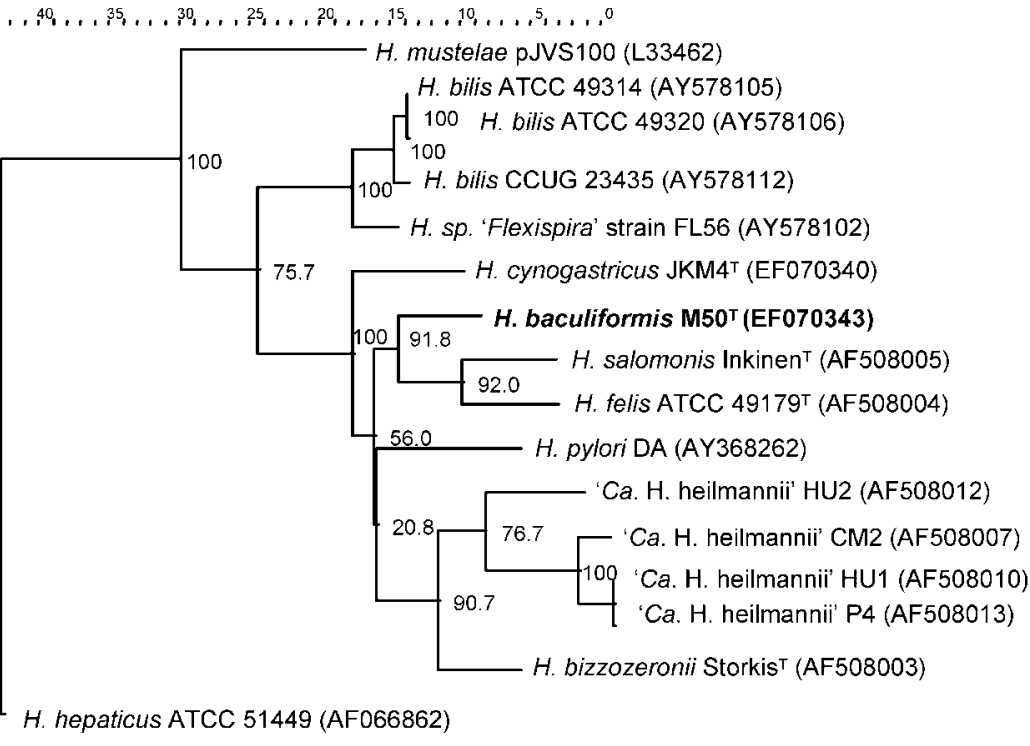

Fig. 2. A phylogenetic tree, reconstructed from genetic distances, based on the partial ure $A$ and $u r e B$ gene sequences for $H$. baculiformis and other urease-positive Helicobacter species. Bootstrap values are indicated. Bar, $45 \%$ divergence. 


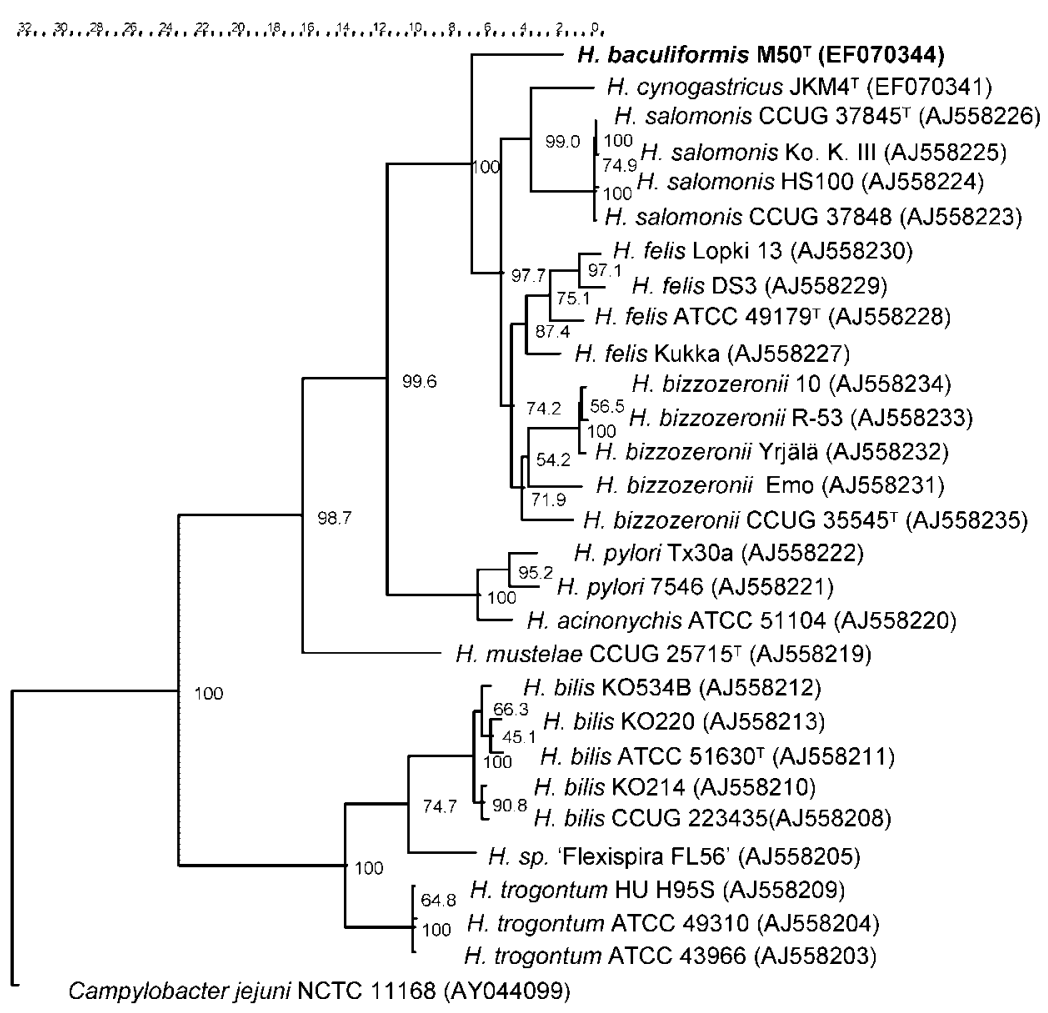

Fig. 3. A phylogenetic tree, reconstructed from genetic distances, based on the partial hsp60 gene sequences for $\mathrm{H}$. baculiformis sp.

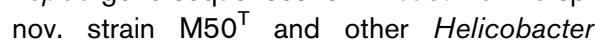
species. Bootstrap values are indicated. Bar, $32 \%$ divergence. constructed using the neighbour-joining method and is shown in Fig. 2. Highest similarity (77-81\%) was obtained with sequences from $H$. felis strains. Gene sequence similarities of $78-80 \%, 75-76 \%, 73-75 \%, 72-74 \%$ and $71 \%$ were obtained to $H$. salomonis, $H$. bizzozeronii, ' $C a$. H. suis', ' $\mathrm{Ca}$. H. heilmannii' and $H$. cynogastricus, respectively. The results of comparisons of the urease sequences of strain $\mathrm{M} 50^{\mathrm{T}}$ with other gastric Helicobacter species are shown in a distance matrix (see Supplementary Table S2 available in IJSEM Online).
Conserved partial $60 \mathrm{kDa}$ heat-shock protein (HSP60) gene sequences have also been shown to give additional phylogenetic information that is useful for differentiating Helicobacter species (Mikkonen et al., 2004). A 515 bp sequence (GenBank accession no. EF070344) obtained from isolate $\mathrm{M} 50^{\mathrm{T}}$ using the methodology described by Mikkonen et al. (2004) placed this taxon into the cluster of $H$. felis, H. bizzozeronii, $H$. salomonis and $H$. cynogastricus, confirming the results based on $16 \mathrm{~S}$ rRNA gene and ureAB sequence analysis. Only 70-75\% similarity was obtained
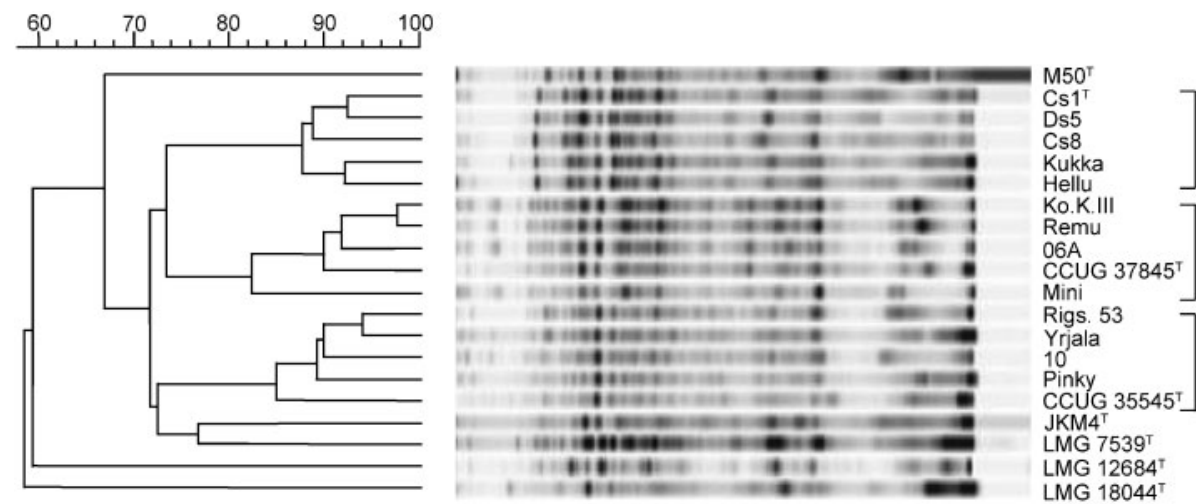

H. baculiformis

H. felis

H. salomonis

H. bizzozeronii

H. cynogastricus

H. pylori

$H$. acinonychis

H. mustelae

Fig. 4. Dendrogram derived from the numerical analysis of the whole-cell protein profiles of strain $\mathrm{M} 50^{\top}$ and $H e l i c o b a c t e r$ reference strains. Bar, $40 \%$ divergence. 
with these species, yielding sufficient difference to consign isolate $\mathrm{M} 50^{\mathrm{T}}$ into a new taxon. Multiple aligned distances are shown in Supplementary Table S3 (see IJSEM Online). A phylogenetic tree obtained from this matrix using the neighbour-joining method is shown in Fig. 3.

Dewhirst et al. (2005) recently suggested that 16S rRNA gene sequence data do not always faithfully reflect phylogenetic relationships and that 23S rRNA gene sequence data are significantly more reliable for identification and classification of helicobacters due to the threefoldhigher number of informative bases. Therefore, we also attempted to amplify the 23S rRNA gene of strain $\mathrm{M} 50^{\mathrm{T}}$ using PCR primers O68 and M89 (Dewhirst et al., 2005). However, no amplicons were obtained in this PCR. DNA of $H$. cynogastricus strain $\mathrm{JKM} 4^{\mathrm{T}}$ was used as a positive control and did yield a band of the expected length (approx. $2730 \mathrm{bp}$ ).

Polyacrylamide gel electrophoresis (PAGE) of whole-cell proteins of strain $\mathrm{M} 50^{\mathrm{T}}$ was performed in order to confirm its distinct taxonomic status. For this purpose, strain $\mathrm{M} 50^{\mathrm{T}}$ was grown on BHI agar supplemented with $5 \%(\mathrm{v} / \mathrm{v})$ horse blood and was incubated at $37{ }^{\circ} \mathrm{C}$ in a micro-aerobic atmosphere as described above. A whole-cell protein extract was prepared and sodium dodecyl sulphate PAGE was performed as described previously (Pot et al., 1994). Whole-cell protein profiles of $H$. bizzozeronii, $H$. salomonis, $H$. felis and H. cynogastricus reference strains and of type and reference strains of other Helicobacter species were available from previous studies (Jalava et al., 1998, 2001; Van den Bulck et al., 2006). Densitometric analysis, normalization and interpolation of the protein profiles, and numerical analysis were performed using the GelCompar software package version 4.2 (Applied Maths). The similarity between all pairs of traces was expressed by the Pearson product moment correlation coefficient presented as percentages of similarity. This analysis demonstrated that strain $\mathrm{M} 50^{\mathrm{T}}$ can be clearly distinguished from all of its cultured closest relatives (Fig. 4). Given the correlation between level of whole-cell protein electrophoretic similarity and DNA-DNA hybridization (Dewhirst et al., 2000b; Vandamme et al., 1996), these results confirm that strain $\mathrm{M} 50^{\mathrm{T}}$ represents a species distinct from its nearest phylogenetic neighbours.

The morphology of the strain $\mathrm{M} 50^{\mathrm{T}}$ was studied by means of transmission electron microscopy, after negative staining with $2 \%$ uranyl acetate (Houf et al., 2005) and after ultrathin sectioning as described by Mast et al. (2005) (Fig. 5).

Cells were large, slender to slightly spiral rods which were approximately $10 \mu \mathrm{m}$ long and approximately $1 \mu \mathrm{m}$ wide. Up to 11 sheathed flagella were located at both ends. The flagella were blunt-ended and the terminal diameter was wider than the average diameter of the flagellar body. Four periplasmic fibrils were found running along the external side of the helix on every cell of strain $\mathrm{M} 50^{\mathrm{T}}$. Coccoid forms were observed in cultures older than 4 days.
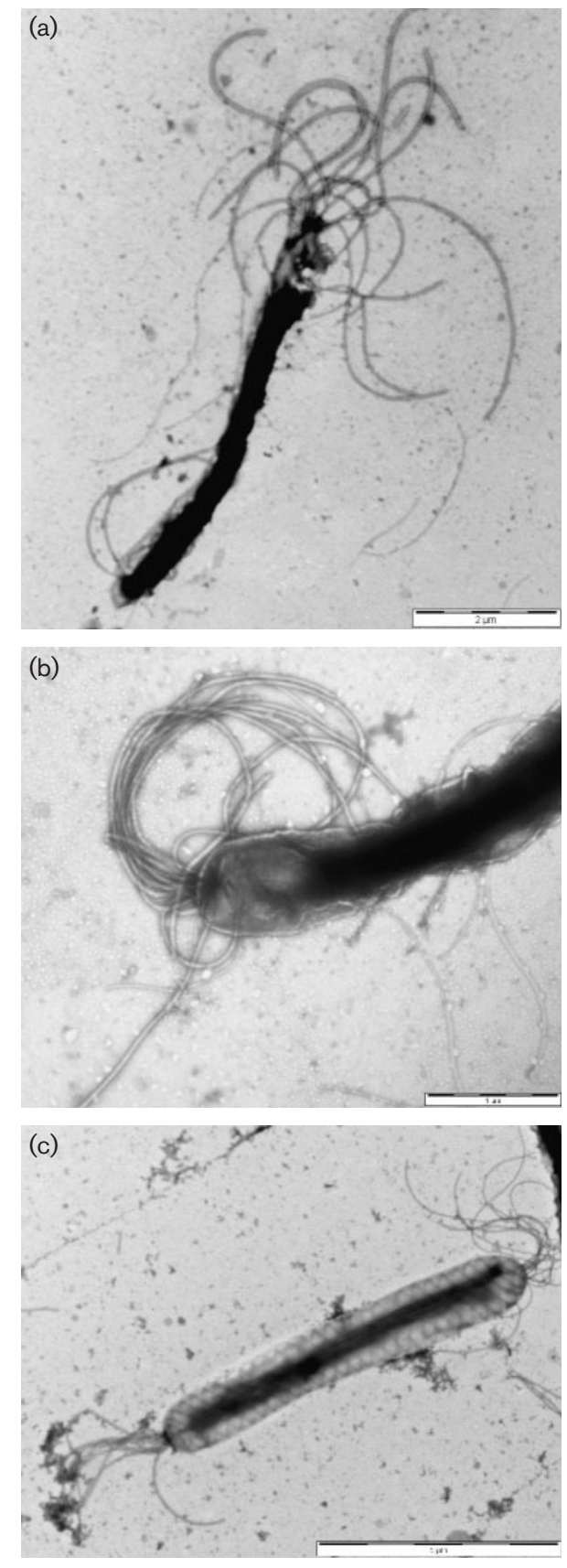

Fig. 5. TEM images of cells of $H$. baculiformis sp. nov. strain

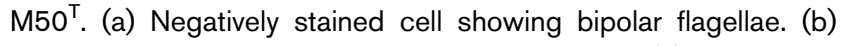
Negatively stained cell showing sheathed flagellae. (c) Periplasmic fibrils coiling around the cell body. Bars, $2 \mu \mathrm{m}$ (a), $1 \mu \mathrm{m}$ (b) and $5 \mu \mathrm{m}$ (c).

Biochemical and tolerance tests were carried out according to the recommendations of Dewhirst et al. (2000b). Growth of strain $\mathrm{M}^{\mathrm{T}} 0^{\mathrm{T}}$ was examined on Brucella agar supplemented with $20 \%$ fetal calf serum at 25,37 and $42{ }^{\circ} \mathrm{C}$ under microaerobic conditions, and at $37{ }^{\circ} \mathrm{C}$ under aerobic, microaerobic and anaerobic conditions. Tolerance to $1 \%$ bile, $1 \%$ glycine and $1.5 \% \mathrm{NaCl}$ was determined on 
Brucella agar with $20 \%$ fetal calf serum. Growth was tested on BHI agar, Brucella agar and Mueller-Hinton agar, supplemented with $20 \%$ fetal calf serum or $10 \%$ defibrinated horse blood. All media were incubated for 7 days in a microaerobic atmosphere at $37^{\circ} \mathrm{C}$. The isolates were Gram stained and examined for catalase activity by standard microbiological methods. Oxidase activity was determined with Bactident Oxidase strips (Merck). With the API Campy identification system (bioMérieux), the following biochemical analyses were performed: urease activity, reduction of nitrates, esterase activity, hydrolysis of hippurate, $\gamma$-glutamyltransferase activity, reduction of triphenyl-tetrazoliumchloride (TTC), alkaline phosphatase activity and pyrrolidonyl, L-arginine and L-aspartate arylamidase activities. Tests were read after $24 \mathrm{~h}$ of incubation at $37^{\circ} \mathrm{C}$ in an aerobic atmosphere. Indoxyl acetate hydrolysis was determined as previously described by Mills \& Gherna (1987). Susceptibility to cephalothin and nalidixic acid (both at $30 \mu \mathrm{g}$ per disc; Becton Dickinson) was examined on BHI agar plates supplemented with $10 \%$ defibrinated horse blood, as recommended by Dewhirst et al. (2000b). Growth in the presence of metronidazole was determined with BHI agar (Oxoid) containing $10 \%$ horse blood and $5 \mu \mathrm{g} \mathrm{ml}^{-1}$ of the test compound. A detailed list of results is given in the description section below and a comparison of the most important phenotypic characteristics of strain $\mathrm{M} 50^{\mathrm{T}}$ with those of other Helicobacter species is shown in Table 1.

In conclusion, the combined evidence derived from phylogenetic analysis of the $16 \mathrm{~S}$ rRNA, ureAB and HSP60 genes and whole-cell protein electrophoresis demonstrates that strain $\mathrm{M}_{50}{ }^{\mathrm{T}}$ represents a novel species within the phylogenetic lineage that currently consists of $\mathrm{H}$. felis, $\mathrm{H}$. bizzozeronii, $H$. salomonis, $H$. cynogastricus and 'Candidatus H. heilmannii'.

\section{Description of Helicobacter baculiformis sp. nov.}

Helicobacter baculiformis (ba.cu.li.for'mis. L. n. baculus rod; L. suff. -formis of the shape of; N.L. masc. adj. baculiformis rod-shaped).

Cells are large, slender to slightly spiral rods that are approximately $10 \mu \mathrm{m}$ long and approximately $1 \mu \mathrm{m}$ wide. They possess four periplasmic fibrils running along the external side of the helix. Coccoid cells predominate in older cultures. Cells are Gram-negative and non-sporulating. They are motile by means of tufts of up to 11 sheathed flagella at both ends of the cells. The flagella are bluntended and the terminal diameter is wider than the average diameter of the flagellar body. Growth is observed on BHI agar, Brucella agar and on Mueller-Hinton agar supplemented with $20 \%$ fetal calf serum or with $10 \%$ defibrinated horse blood. Grows in micro-aerophilic conditions as well as in a $5 \% \mathrm{CO}_{2}$-supplemented atmosphere. Weak growth is seen after anaerobic incubation. Grows at $37{ }^{\circ} \mathrm{C}$, but not at $25{ }^{\circ} \mathrm{C}$ or $42{ }^{\circ} \mathrm{C}$. No growth on media supplemented with $1.5 \% \mathrm{NaCl}, 1 \%$ glycine or $1 \%$ ox bile. Oxidase-, catalase- and urease-positive. Reduces nitrate and TTC and tests positive for esterase, $\gamma$-glutamyl transpeptidase, L-arginine arylamidase and alkaline phosphatase. Hippurate and indoxyl acetate are

Table 1. Differential characteristics of $H$. baculiformis sp. nov. $M 50^{\top}$ and other species of the genus Helicobacter

Taxa: 1, H. baculiformis sp. nov. (this study); 2, H. cynogastricus; 3, H. bizzozeronii; 4, H. felis; 5, H. salomonis; 6, H. pylori; 7, H. acinonychis; 8, H. bilis; 9, H. trogontum; 10, H. mustelae; 11, H. nemestrinae; 12, H. muridarum; 13, H. aurati. Data were obtained from Bronsdon et al. (1991), Dewhirst et al. (2000a), Eaton et al. (1993), Fox et al. (1988, 1995), Hänninen et al. (1996, 2005), Jalava et al. (1997), Lee et al. (1988, 1992), Mendes et al. (1996), Patterson et al. (2000) and Van den Bulck et al. (2006). +, 100\% of strains positive; -, 0\% strains positive; (+), 80-94\% strains positive; (-), 7-33\% strains positive; $\mathrm{v}, 42-66 \%$ strains positive; ND, not determined; NA, not available; R, resistant; s, susceptible; I, intermediate; $\mathrm{BP}$, bipolar; MP, monopolar; LP, lateral polar. All taxa are positive for catalase production and possess sheathed flagella.

\begin{tabular}{|c|c|c|c|c|c|c|c|c|c|c|c|c|c|}
\hline Characteristic & 1 & 2 & 3 & 4 & 5 & 6 & 7 & 8 & 9 & 10 & 11 & 12 & 13 \\
\hline Cell length $(\mu \mathrm{m})$ & 10 & $10-18$ & $5-10$ & $5-7.5$ & $5-7$ & $2.5-5$ & $1.2-2$ & $4-5$ & $4-6$ & 2 & NA & $3.5-5$ & $4-8$ \\
\hline Cell width $(\mu \mathrm{m})$ & 1 & $0.8-1.0$ & 0.3 & 0.4 & $0.8-1.2$ & $0.5-1.0$ & 0.3 & 0.5 & $0.6-0.7$ & 0.5 & NA & $0.5-0.6$ & 0.6 \\
\hline Nitrate reduction & + & + & + & + & + & - & - & + & + & + & - & - & - \\
\hline Urease & + & + & $(+)$ & $(+)$ & + & + & + & + & + & + & + & + & + \\
\hline Alkaline phosphate hydrolysis & + & + & $\mathrm{V}$ & $\mathrm{V}$ & $\mathrm{V}$ & + & + & - & - & + & + & + & - \\
\hline$\gamma$-Glutamyl transpeptidase & + & + & + & + & + & + & + & + & + & + & $\mathrm{ND}$ & + & + \\
\hline Indoxyl acetate hydrolysis & - & - & $(-)$ & $(-)$ & $(-)$ & $(-)$ & $(-)$ & - & - & + & - & - & + \\
\hline Growth at $42{ }^{\circ} \mathrm{C}$ & - & - & $\mathrm{V}$ & $\mathrm{V}$ & - & $(-)$ & $(-)$ & + & + & $\mathrm{V}$ & + & - & + \\
\hline Growth on $1 \%$ glycine & - & - & $(-)$ & - & - & - & - & + & $\mathrm{ND}$ & - & - & - & - \\
\hline \multicolumn{14}{|l|}{ Susceptibility to: } \\
\hline Nalidixic acid $(30 \mu \mathrm{g})$ & I & ND & $\mathrm{R}$ & $\mathrm{R}$ & $\mathrm{R}$ & $\mathrm{R}$ & $\mathrm{R}$ & $\mathrm{R}$ & $\mathrm{R}$ & s & $\mathrm{R}$ & $\mathrm{R}$ & s \\
\hline Cephalothin $(30 \mu \mathrm{g})$ & $\mathrm{R}$ & ND & s & s & s & s & s & $\mathrm{R}$ & $\mathrm{R}$ & $\mathrm{R}$ & s & $\mathrm{R}$ & $\mathrm{R}$ \\
\hline Periplasmic fibril & + & + & - & + & - & - & - & + & + & - & - & + & + \\
\hline No. of flagella/cell & 11 & $6-12$ & $10-20$ & $14-20$ & $10-23$ & $4-8$ & $2-5$ & $3-14$ & $5-7$ & $4-8$ & $4-8$ & $10-14$ & $7-10$ \\
\hline Distribution of flagella & ВР & вР & BP & ВР & BP & MP & MP & ВР & вр & LP & BP & ВР & вР \\
\hline
\end{tabular}


not hydrolysed and activity of pyrrolidonyl arylamidase and L-aspartate arylamidase is not detected. The type strain, strain $\mathrm{M} 50^{\mathrm{T}}$, is resistant to cephalothin $(30 \mu \mathrm{g})$ and intermediately susceptible to nalidixic acid $(30 \mu \mathrm{g})$. The clinical significance of $H$. baculiformis is unknown.

The type strain, strain $\mathrm{M} 50^{\mathrm{T}}\left(=\mathrm{LMG} 23839^{\mathrm{T}}=\mathrm{CCUG}\right.$ $\left.53816^{\mathrm{T}}\right)$, was isolated from the gastric mucosa of a cat.

\section{Acknowledgements}

This work was supported by the Research Fund of Ghent University, Belgium, Code GOA12050602. The authors are very grateful to Jurgen De Craene for his excellent technical assistance.

\section{References}

Andersen, L. P., Boye, K., Blom, J., Holck, S., Norgaard, A. \& Elsborg, L. (1999). Characterization of a culturable "Gastrospirillum hominis" (Helicobacter heilmannii) strain isolated from human gastric mucosa. J Clin Microbiol 37, 1069-1076.

Baele, M., Devriese, L. A. \& Haesebrouck, F. (2001). Lactobacillus agilis is an important component of the pigeon crop flora. J Appl Microbiol 91, 488-491.

Baele, M., Van den Bulck, K., Decostere, A., Vandamme, P., Hanninen, M. L., Ducatelle, R. \& Haesebrouck, F. (2004). Multiplex PCR assay for differentiation of Helicobacter felis, H. bizzozeronii, and H. salomonis. J Clin Microbiol 42, 1115-1122.

Bronsdon, M. A., Goodwin, C. S., Sly, L. I., Chilvers, T. \& Schoenknecht, F. D. (1991). Helicobacter nemestrinae sp. nov., a spiral bacterium found in the stomach of a pigtailed macaque (Macaca nemestrina). Int J Syst Bacteriol 41, 148-153.

Coenye, T., Falsen, E., Vancanneyt, M., Hoste, B., Govan, J. R. W., Kersters, K. \& Vandamme, P. (1999). Classification of Alcaligenes faecalis-like isolates from the environment and human clinical samples as Ralstonia gilardii sp. nov. Int J Syst Bacteriol 49, 405-413.

Dewhirst, F. E., Fox, J. G., Mendes, E. N., Paster, B. J., Gates, C. E., Kirkbride, C. A. \& Eaton, K. A. (2000a). 'Flexispira rappini' strains represent at least 10 Helicobacter taxa. Int J Syst Evol Microbiol 50, 1781-1787.

Dewhirst, F. E., Fox, J. G. \& On, S. L. W. (2000b). Recommended minimal standards for describing new species of the genus Helicobacter. Int J Syst Evol Microbiol 50, 2231-2237.

Dewhirst, F. E., Shen, Z. L., Scimeca, M. S., Stokes, L. N., Boumenna, T., Chen, T. T., Paster, B. J. \& Fox, J. G. (2005). Discordant $16 \mathrm{~S}$ and $23 \mathrm{~S}$ rRNA gene phylogenies for the genus Helicobacter. implications for phylogenetic inference and systematics. J Bacteriol 187, 6106-6118.

Eaton, K. A., Dewhirst, F. E., Radin, M. J., Fox, J. G., Paster, B. J., Krakowka, S. \& Morgan, D. R. (1993). Helicobacter acinonyx sp. nov., isolated from cheetahs with gastritis. Int J Syst Bacteriol 43, 99-106.

Eaton, K. A., Dewhirst, F. E., Paster, B. J., Tzellas, N., Coleman, B. E., Paola, J. \& Sherding, R. (1996). Prevalence and varieties of Helicobacter species in dogs from random sources and pet dogs: animal and public health implications. J Clin Microbiol 34, 3165-3170.

Fox, J. G., Taylor, N. S., Edmonds, P. \& Brenner, D. J. (1988). Campylobacter pylori subsp. mustelae subsp. nov., isolated from the gastric mucosa of ferrets (Mustela putorius furo), and an emended description of Campylobacter pylori. Int J Syst Bacteriol 38, 367-370.

Fox, J. G., Yan, L. L., Dewhirst, F. E., Paster, B. J., Shames, B., Murphy, J. C., Howard, A., Belcher, J. C. \& Mendes, E. N. (1995). Helicobacter bilis sp. nov., a novel Helicobacter species isolated from bile, livers, and intestines of aged, inbred mice. J Clin Microbiol 33, 445-454.

Gruntar, I., Mehle, J., Krt, B., Ocepek, M., Gombac, M., Cerne, M. \& Pogacnik, M. (2003). New approaches in isolation of Helicobacter spp. from gastric mucosa in dogs. Int J Med Microbiol 293 (Suppl.), 65.

Hänninen, M. L., Happonen, I., Saari, S. \& Jalava, K. (1996). Culture and characteristics of Helicobacter bizzozeronii, a new canine gastric Helicobacter sp. Int J Syst Bacteriol 46, 160-166.

Hänninen, M. L., Utriainen, M., Happonen, I. \& Dewhirst, F. E. (2003). Helicobacter sp. flexispira 16S rDNA taxa 1,4 and 5 and Finnish porcine Helicobacter isolates are members of the species Helicobacter trogontum (taxon 6). Int J Syst Evol Microbiol 53, 425-433.

Hänninen, M. L., Kärenlampi, R. I., Koort, J. M. K., Mikkonen, T. \& Björkroth, K. J. (2005). Extension of the species Helicobacter bilis to include the reference strains of Helicobacter sp. flexispira taxa 2, 3 and 8 and Finnish canine and feline flexispira strains. Int $J$ Syst Evol Microbiol 55, 891-898.

Houf, K., On, S. L. W., Coenye, T., Mast, J., Van Hoof, J. \& Vandamme, P. (2005). Arcobacter cibarius sp nov., isolated from broiler carcasses. Int $J$ Syst Evol Microbiol 55, 713-717.

Jalava, K., Kaartinen, M., Utriainen, M., Happonen, I. \& Hanninen, M. L. (1997). Helicobacter salomonis sp. nov., a canine gastric Helicobacter sp. related to Helicobacter felis and Helicobacter bizzozeronii. Int J Syst Bacteriol 47, 975-982.

Jalava, K., On, S. L. W., Vandamme, P. A. R., Happonen, I., Sukura, A. \& Hanninen, M. L. (1998). Isolation and identification of Helicobacter spp. from canine and feline gastric mucosa. Appl Environ Microbiol 64, 3998-4006.

Jalava, K., On, S. L. W., Harrington, C. S., Andersen, L. P., Hanninen, M. L. \& Vandamme, P. (2001). A cultured strain of "Helicobacter heilmannii", a human gastric pathogen, identified as $H$. bizzozeronii: evidence for zoonotic potential of Helicobacter. Emerg Infect Dis 7, 1036-1038.

Lee, A., Hazell, S. L., O'Rourke, J. \& Kouprach, S. (1988). Isolation of a spiral-shaped bacterium from the cat stomach. Infect Immun 56, 2843-2850.

Lee, A., Phillips, M. W., O’Rourke, J. L., Paster, B. J., Dewhirst, F. E., Fraser, G. J., Fox, J. G., Sly, L. I., Romaniuk, P. J. \& other authors (1992). Helicobacter muridarum sp. nov., a microaerophilic helical bacterium with a novel ultrastructure isolated from the intestinal mucosa of rodents. Int J Syst Bacteriol 42, 27-36.

Mast, J., Nanbru, C., van den Berg, T. \& Meulemans, G. (2005). Ultrastructural changes of the tracheal epithelium after vaccination of day-old chickens with the La Sota strain of Newcastle disease virus. Vet Pathol 42, 559-565.

Mendes, E. N., Queiroz, D. M. M., Dewhirst, F. E., Paster, B. J., Moura, S. B. \& Fox, J. G. (1996). Helicobacter trogontum sp. nov., isolated from the rat intestine. Int J Syst Bacteriol 46, 916-921.

Mikkonen, T. P., Karenlampi, R. I. \& Hänninen, M. L. (2004). Phylogenetic analysis of gastric and enterohepatic Helicobacter species based on partial HSP60 gene sequences. Int J Syst Evol Microbiol 54, 753-758.

Mills, C. K. \& Gherna, R. L. (1987). Hydrolysis of indoxyl acetate by Campylobacter species. J Clin Microbiol 25, 1560-1561.

O'Rourke, J. L., Solnick, J. V., Neilan, B. A., Seidel, K., Hayter, R., Hansen, L. M. \& Lee, A. (2004). Description of 'Candidatus Helicobacter heilmannii' based on DNA sequence analysis of $16 \mathrm{~S}$ rRNA and urease genes. Int J Syst Evol Microbiol 54, 2203-2211.

Patterson, M. M., Schrenzel, M. D., Feng, Y., Xu, S., Dewhirst, F. E., Paster, B. J., Thibodeau, S. A., Versalovic, J. \& Fox, J. G. (2000). Helicobacter aurati sp. nov., a urease-positive Helicobacter species cultured from gastrointestinal tissues of Syrian hamsters. J Clin Microbiol 38, 3722-3728. 
Pot, B., Devriese, L. A., Hommez, J., Miry, C., Vandemeulebroecke, K., Kersters, K. \& Haesebrouck, F. (1994). Characterization and identification of Vagococcus fluvialis strains isolated from domestic animals. J Appl Bacteriol 77, 362-369.

Solnick, J. V., O’Rourke, J., Lee, A., Paster, B. J., Dewhirst, F. E. \& Tompkins, L. S. (1993). An uncultured gastric spiral organism is a newly identified Helicobacter in humans. J Infect Dis 168, 379-385.

Van den Bulck, K., Decostere, A., Baele, M., Driessen, A., Debongnie, J. C., Burette, A., Stolte, M., Ducatelle, R. \&
Haesebrouck, F. (2005). Identification of non-Helicobacter pylori spiral organisms in gastric samples from humans, dogs and cats. J Clin Microbiol 43, 2256-2260.

Van den Bulck, K., Decostere, A., Baele, M., Vandamme, P., Mast, J., Ducatelle, R. \& Haesebrouck, F. (2006). Helicobacter cynogastricus sp. nov., isolated from the canine gastric mucosa. Int J Syst Evol Microbiol 56, 1559-1564.

Vandamme, P., Pot, B., Gillis, M., De Vos, P., Kersters, K. \& Swings, J. (1996). Polyphasic taxonomy, a consensus approach to bacterial classification. Microbiol Rev 60, 407-438. 